\title{
Mg-Fe-RICH AMPHIBOLES ASSOCIATED TO PYROCLASTICS FROM SANTORINI ISLAND, SOUTH AEGEAN SEA VOLCANIC ARC, GREECE
}

\author{
Kitsopoulos K. ${ }^{1}$ \\ ${ }^{I}$ Leicester University, Geology Department, Leicester, LE1 7RH, UK
}

\begin{abstract}
Amphibole bearing volcanic products in Santorini are restricted to the early volcanic activity expressed in the Akrotiri peninsula. This fact distinguishes these early products from the rest of the volcanic rocks of Santorini. The Fe-Mg-rich mineral phases, associated to the Akrotiri silicic pyroclastics which were analysed can be classified as $\mathrm{Mg}$-Fe rich type of amphibole. This type of amphibole has not been reported before in volcanic rocks from the South Aegean Volcanic Arcr. The presence of such a high Fe-Mg mineral phase in silicic pyroclastics in Santorini is constant with the involvement of primitive, mantle derived, mafic magmas, with some considerable water content, and which have been differentiated, before they are mixed with more silicic magmas at a shallower crustal level.
\end{abstract}

Key words: Silicic volcanics, magma mixing, mineral chemistry.

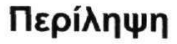

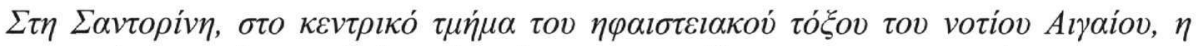

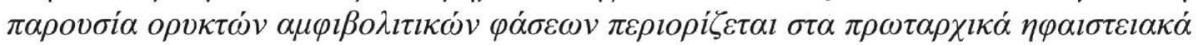

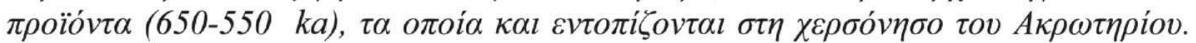

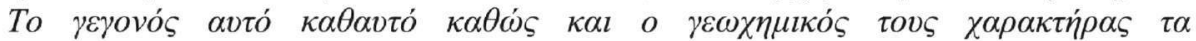

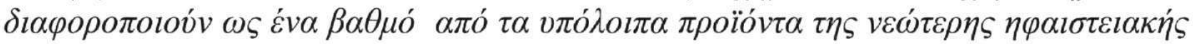

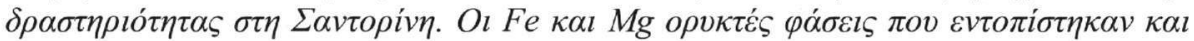

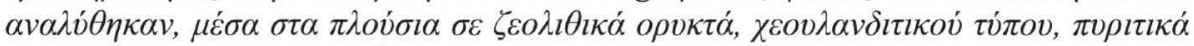

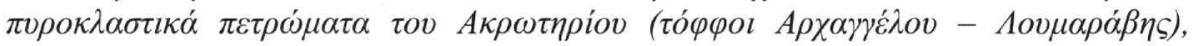

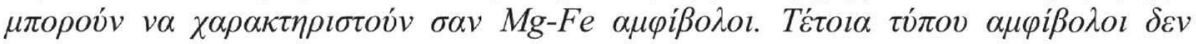

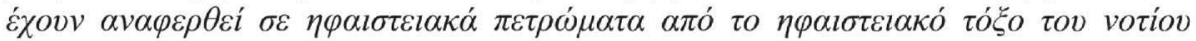

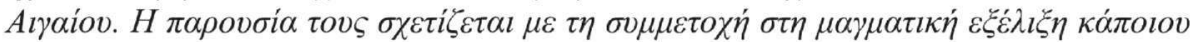

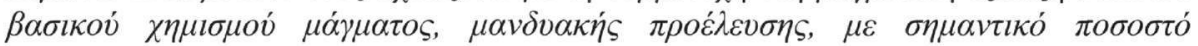

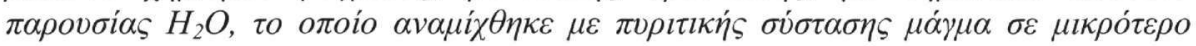

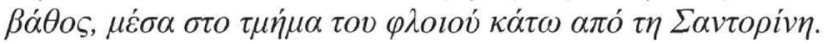

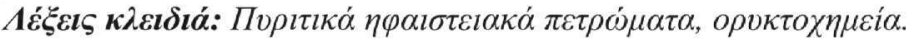

\section{Introduction}

It is well known that the extensive solid solutions shown by the amphiboles, alongside with their widespread occurrence has caused numerous difficulties in devising a rational nomenclature for the group. It was not until 1978 that a standard internationally agreed amphibole nomenclature was 
first published (IMA78; Leake 1978), following a large period of 13 years of conferring, by the Subcommittee on Amphiboles of the International Mineralogical Association"s Commission on New Minerals and Mineral Names (IMA CNMMN). Further discoveries and the required revisions had led to the present scheme, fully presented and described in Leake et al. $(1997,2004)$ and Burke and Leake (2005).

The current amphibole's classification scheme comprises of five groups:

Group 1. Magnesium-iron-manganese-lithium group. Sum of L-type ions ${ }^{B}(\mathrm{Mg}, \mathrm{Fe}, \mathrm{Mn}, \mathrm{Li}) \geq 1.50$ apfu (atom per formula unit). (L-type ions are divalent $\mathrm{Mg}, \mathrm{Fe}, \mathrm{Mn}, \mathrm{Zn}, \mathrm{Ni}$, Co etc and $\mathrm{Li}$, as described in IMA97).

Group 2. Calcic group. ${ }^{\mathrm{B}}\left(\mathrm{Mg}, \mathrm{Fe}^{2+}, \mathrm{Mn}^{2+}, \mathrm{Li}\right) \leq 0.50,{ }^{\mathrm{B}}(\mathrm{Ca}, \mathrm{Na}) \geq 1.00$ and ${ }^{\mathrm{B}} \mathrm{Na}<0.50$ apfu.

Group 3. Sodic-calcic group. ${ }^{\mathrm{B}}\left(\mathrm{Mg}, \mathrm{Fe}^{2+}, \mathrm{Mn}^{2+}, \mathrm{Li}\right) \leq 0.50,{ }^{\mathrm{B}}(\mathrm{Ca}, \mathrm{Na}) \geq 1.00$, and $0.50 \leq{ }^{\mathrm{B}} \mathrm{Na}<$ $1.50 \mathrm{apfu}$,

Group 4. Sodic group. ${ }^{\mathrm{B}}\left(\mathrm{Mg}, \mathrm{Fe}^{2+}, \mathrm{Mn}^{2+}, \mathrm{Li}\right) \leq 0.50$, and ${ }^{\mathrm{B}} \mathrm{Na} \geq 1.50$ apfu.

Group 5. Sodium-calcium-magnesium-iron-manganese-lithium group. $0.50<{ }^{\mathrm{B}}\left(\mathrm{Mg}, \mathrm{Fe}^{2+}, \mathrm{Mn}^{2+}\right.$, Li) $<1.50$ and $0.50 \leq^{\mathrm{B}}(\mathrm{Ca}, \mathrm{Na}) \leq 1.50$ apfu.

The first four groups are the same to the IMA97 classification. Group 5 was added in 2004 by taking into account the complete solid-solution between $\mathrm{Li}$ and $\mathrm{Na}$ at $\mathrm{B}$ sites of amphiboles (Oberti et al. 2003).

Generally, the classification scheme consists of 34 root names (e.g., glaucophane) with a range of compulsorily used prefixes (e.g., ferro) to indicate particular richness in certain elements (to avoid unnecessary proliferation of the already large number of root names), and several optionally usable modifiers (e.g., titanian) for less important substitutions. It should be noted that prefixes are an essential part of a mineral name (Nickel and Grice 1998).

\section{Geological Setting}

\subsection{Santorini Island - Akrotiri Peninsula}

The three islands of Santorini (Thera) (Santorini), Therasia and Aspronisi are the remnants of the Santorini stratocone, while the Old and New Kameni are the products of a much later volcanism. According to Pichler and Kussmaul (1972) a calk-alkaline, high-alumina, basalt-andesite-dacite type of volcanism was expressed in Santorini island from eight centres. The complete evolution of the Santorini volcanic complex has been studied by Druitt et al (1999), while Nichols (1971) and Huijsmans et al. (1988) focused mostly on the younger volcanic products. The majority of the volcanics around the Akrotiri peninsula are considered to be the first volcanic products in Santorini (Pliocene-Pleistocene). They have been studied by Davis et al (1998) and Dietrich et al. (1998). The geology of the Akrotiri Peninsula is given in Figure 1. Two volcanic suites have been recognised; the silicic Lumaravi-Archangelos and the mafic Akrotiri volcanic suites. The Lumaravi-Archangelos volcanic suite is composed of submarine domes, coulees, and hyaloclastite aprons (Rhyodacites of Akrotiri, rl in Fig. 1) intercalating with vitric tuffs, pumice breccias and conglomerates (Tuffs of Akrotiri, rpl in Fig. 1). The pyroclastic materials are the expression of three different centres. The white to pale green tuffs originally consisted of ash and/or lapilli, which were vitric and crystalline in composition. Agglomerated bands consisting of gray to green dacitic cognate xenoliths up to $15 \mathrm{~cm}$ long form tuff breccia. The exposed thickness is about $160 \mathrm{~m}$ but some borehole investigations recorded at least $220 \mathrm{~m}$. Fouque (1879) found Pliocene marine fossils indicating deposition in shallow water, although no evidence of sorting was reported by him. The mafic Akrotiri volcanic suite is composed of small domes and flows of andesites and basalts. 


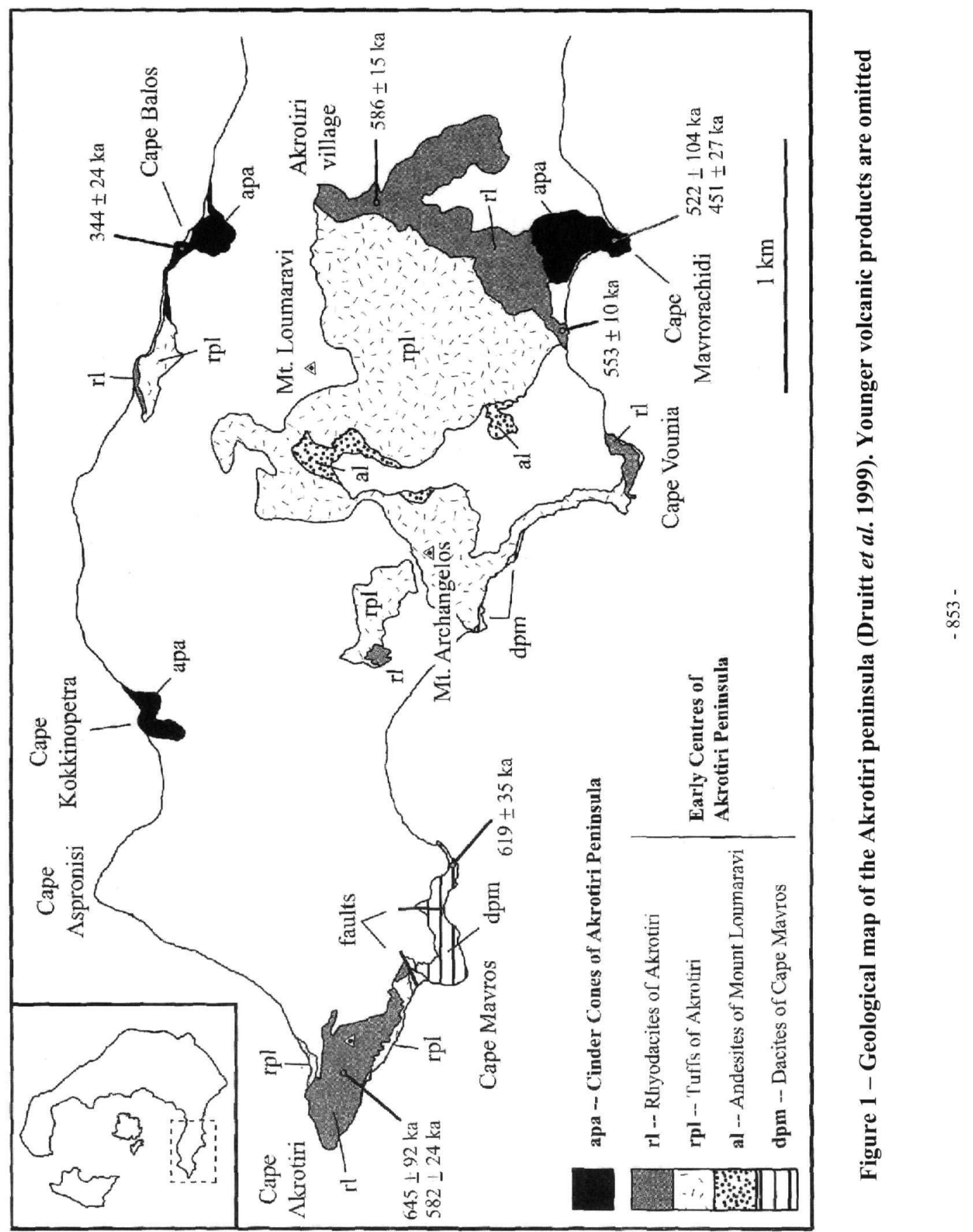




\section{Materials and Methods}

\subsection{Akrotiri pre-Caldera Zeolitized Pyroclastics}

The samples used in this study were collected from the "Tuffs of Akrotiri" unit of Figure 1, which has undergone substantial zeolitization.

The zeolitization of the pyroclastics involved the development of heulandite type of minerals and illite/smectite which have replaced the vitric matrix, forming characteristic pseudomorphs after the inner parts of glass shards. Authigenic opal-CT and cristobalite, halite, and pyrogenic phenocrysts of feldspars, amphiboles and Fe-Ti oxides complete the mineralogy. By using thermal tests the heulandite type of minerals were classified as heulandites type 3 , i.e. clinoptilolites.

Tsolis-Katagas and Katagas (1989) proposed that the formation of zeolites resulted from the activity of interstitial water into the pile of the volcaniclastic material. The different mineralogical assemblages and compositions were attributed by the same authors to variations in the heat flow, the ionic activity in the interstitial waters, and the permeability. Kitsopoulos (1996) suggested that the formation of heulandite type of minerals did not exactly follow a "glass dissolution" path, but it involved a number of continuous reactions. These reactions and their subsequent results were often controlled in numerous small closed sub-systems, even within the area of individual glass particles. The formation of zeolites did not proceed through a form of complete dissolution, but a continuous two end-members equilibrium reaction between the solid and the fluid components of a rather closed system.

The silicic pyroclastics range in $\mathrm{SiO}_{2}$ from $61-75 \%$, with a mean value of $67.2 \%$, therefore, they could be classified as rhyodacites-dacites to low-Si rhyolites (Kitsopoulos 1995). Because of the zeolitization process that the pyroclastics had undergone, the trace element discrimination diagram $\mathrm{Nb} / \mathrm{Y}$ vs. $\mathrm{Zr} / \mathrm{TiO}_{2}$, proposed by Winchester and Floyd (1977), were also applied on the Akrotiri zeolitized pyroclastics, Kitsopoulos et al. (2001) concluded, that the formation of the zeolites should have been mainly facilitated by an acidic precursor, obviously a rhyodacite-dacite type of rock. A small number of the samples used plotted very close to the rhyodacite-dacite/andesite boundary and one in the andesite field, indicating a more basic origin of their precursor. It was also found that there was no change in the alkaline affinity recorded during the eruption of the Akrotiri tuffs, but at the same time some degree of magma differentiation was evidenced.

\subsection{Electron MicroProbe Analysis (EMPA)}

EMPA was used to study the composition of the Mg-Fe-rich mineral phases in the zeolitized tuffs. Carbon-coated polished thin sections were prepared from impregnated samples. The instrument used was a JEOL JXA-8600 Superprobe. The specific probe model carries four wavelength spectrometers (WDS) and is also equipped with a LINK 860 Series 1 Energy Dispersive System (EDS) detector with a $158 \mathrm{eV}$ resolution at $5.8 \mathrm{KeV}$, which is used to analyse crystals with high volatility, and of very small sizes. The beam for the WDS analyses was operated at $15 \mathrm{kV}$ and 30 $\mathrm{nA}$, voltage and current conditions. Wollastonite was used for the standardisation of $\mathrm{Si}$ and $\mathrm{Ca}$, rutile for $\mathrm{Ti}$, jadeite for $\mathrm{Al}$ and $\mathrm{Na}, \mathrm{Fe}_{3} \mathrm{O}_{4}$ for $\mathrm{Fe}$, rhodonite for $\mathrm{Mn}, \mathrm{MgO}$ for $\mathrm{Mg}, \mathrm{CH} 14$ (microcline) for $\mathrm{K}$ and pure $\mathrm{Cr}$ and $\mathrm{Ni}$ for $\mathrm{Cr}$ and $\mathrm{Ni}$ respectively. All the running conditions, crystals and the values of standard used are described in detail by Kitsopoulos (1995) and they are available in the microprobe laboratory of Geology Department of Leicester University, UK.

\section{Results and Discussion}

A set of representative analyses is given in Table 1. The MICA and AMPHR programs have been used for calculating cation proportions and redistributing total $\mathrm{Fe}$ measured to $\mathrm{Fe}^{+2}$ and $\mathrm{Fe}^{+3}$. Since $\mathrm{H}_{2} \mathrm{O}$ and halogen contents are uncertain the formula is calculated on a basis of $23(\mathrm{O})$ with $2(\mathrm{OH}$, $\mathrm{F}, \mathrm{Cl}$ ) assumed. 
Table 1 - Representative amphibole analyses

\begin{tabular}{|c|c|c|c|c|c|c|c|c|c|}
\hline Sample & S1 & $\overline{\text { S1 }}$ & S1 & S1 & $\overline{\mathrm{S} 2}$ & $\overline{S 3}$ & $\overline{\text { S3 }}$ & S3 & S4 \\
\hline $\mathrm{SiO}_{2}$ & 55.40 & 54.80 & 54.63 & 55.35 & 54.97 & 54.71 & 55.39 & 55.19 & 54.75 \\
\hline $\mathrm{TiO}_{2}$ & 0.25 & 0.28 & 0.25 & 0.20 & 0.25 & 0.23 & 0.14 & 0.23 & 0.12 \\
\hline $\mathrm{Al}_{2} \mathrm{O}_{3}$ & 1.51 & 2.02 & 1.64 & 1.20 & 1.66 & 1.56 & 1.04 & 1.78 & 1.23 \\
\hline $\mathrm{FeO}$ & 16.72 & 16.11 & 16.04 & 16.37 & 16.64 & 16.60 & 16.64 & 15.68 & 16.02 \\
\hline $\mathrm{Fe}_{2} \mathrm{O}_{3}$ & - & - & - & - & - & - & - & - & - \\
\hline $\mathrm{MnO}$ & 1.57 & 1.61 & 1.59 & 1.68 & 1.79 & 1.69 & 1.73 & 1.75 & 1.62 \\
\hline $\mathrm{MgO}$ & 21.45 & 20.55 & 21.05 & 21.48 & 20.68 & 20.58 & 21.42 & 21.33 & 21.55 \\
\hline $\mathrm{CaO}$ & 1.32 & 2.32 & 1.88 & 1.26 & 1.31 & 1.29 & 1.29 & 1.87 & 1.23 \\
\hline $\mathrm{Na}_{2} \mathrm{O}$ & 0.32 & 0.44 & 0.34 & 0.27 & 0.34 & 0.32 & 0.22 & 0.36 & 0.26 \\
\hline $\mathrm{K}_{2} \mathrm{O}$ & 0.00 & 0.03 & 0.02 & 0.00 & 0.01 & 0.07 & 0.01 & 0.02 & 0.01 \\
\hline Total & 98.84 & 98.24 & 97.48 & 97.93 & 97.69 & 97.33 & 98.00 & 98.49 & 96.83 \\
\hline $\mathrm{Si}$ & 7.789 & 7.738 & 7.761 & 7.839 & 7.820 & 7.830 & 7.849 & 7.768 & 7.820 \\
\hline${ }^{\mathrm{iv}} \mathrm{Al}$ & 0.211 & 0.262 & 0.239 & 0.161 & 0.180 & 0.170 & 0.151 & 0.232 & 0.180 \\
\hline${ }^{\mathrm{T}}$ Total & 8.000 & 8.000 & 8.000 & 8.000 & 8.000 & 8.000 & 8.000 & 8.000 & 8.000 \\
\hline${ }^{\mathrm{vi}} \mathrm{Al}$ & 0.039 & 0.074 & 0.036 & 0.039 & 0.098 & 0.094 & 0.023 & 0.063 & 0.027 \\
\hline $\mathrm{Ti}$ & 0.026 & 0.030 & 0.027 & 0.021 & 0.027 & 0.025 & 0.015 & 0.024 & 0.013 \\
\hline $\mathrm{Fe}^{+3}$ & 0.206 & 0.255 & 0.247 & 0.154 & 0.125 & 0.128 & 0.160 & 0.222 & 0.000 \\
\hline $\mathrm{Mg}$ & 4.495 & 4.325 & 4.457 & 4.534 & 4.385 & 4.390 & 4.524 & 4.475 & 4.588 \\
\hline${ }^{\mathrm{C}} \mathrm{Fe}^{+2}$ & 0.234 & 0.316 & 0.233 & 0.252 & 0.365 & 0.363 & 0.278 & 0.216 & 0.372 \\
\hline${ }^{\mathrm{C}}$ Total & 5.000 & 5.000 & 5.000 & 5.000 & 5.000 & 5.000 & 5.000 & 5.000 & 5.000 \\
\hline${ }^{\mathrm{B}} \mathrm{Fe}^{+2}$ & 1.526 & 1.331 & 1.426 & 1.533 & 1.489 & 1.496 & 1.534 & 1.407 & 1.542 \\
\hline $\mathrm{Mn}$ & 0.187 & 0.193 & 0.191 & 0.202 & 0.216 & 0.205 & 0.208 & 0.209 & 0.196 \\
\hline $\mathrm{Ca}$ & 0.199 & 0.351 & 0.286 & 0.191 & 0.200 & 0.198 & 0.196 & 0.282 & 0.188 \\
\hline${ }^{\mathrm{B}} \mathrm{Na}$ & 0.087 & 0.125 & 0.097 & 0.074 & 0.095 & 0.101 & 0.062 & 0.102 & 0.074 \\
\hline${ }^{\mathrm{B}}$ Total & 1.999 & 2.000 & 2.000 & 2.000 & 2.000 & 2.000 & 2.000 & 2.000 & 2.000 \\
\hline${ }^{\mathrm{A}} \mathrm{Na}$ & 0.000 & 0.001 & 0.000 & 0.000 & 0.001 & 0.001 & 0.000 & 0.000 & 0.000 \\
\hline $\mathrm{K}$ & 0.000 & 0.005 & 0.004 & 0.000 & 0.002 & 0.013 & 0.002 & 0.004 & 0.002 \\
\hline${ }^{\mathrm{A}}$ Total & 0.000 & 0.006 & 0.004 & 0.000 & 0.003 & 0.014 & 0.002 & 0.004 & 0.002 \\
\hline Total Cations & $\begin{array}{r}15.00 \\
0 \\
\end{array}$ & $\begin{array}{r}15.00 \\
6 \\
\end{array}$ & $\begin{array}{r}15.00 \\
4\end{array}$ & $\begin{array}{r}15.00 \\
0\end{array}$ & $\begin{array}{r}15.00 \\
3\end{array}$ & $\begin{array}{r}15.01 \\
4 \\
\end{array}$ & $\begin{array}{r}15.00 \\
2\end{array}$ & $\begin{array}{r}15.00 \\
4\end{array}$ & $\begin{array}{r}15.00 \\
2\end{array}$ \\
\hline${ }^{\mathrm{B}}(\mathrm{Ca}+\mathrm{Na})$ & 0.286 & 0.476 & 0.383 & 0.265 & 0.295 & 0.299 & 0.258 & 0.384 & 0.262 \\
\hline${ }^{\mathrm{B}}(\mathrm{Mg}, \mathrm{Fe}, \mathrm{Mn}, \mathrm{Li})$ & 1.713 & 1.524 & 1.617 & 1.735 & 1.705 & 1.701 & 1.742 & 1.616 & 1.738 \\
\hline
\end{tabular}


By following the standard amphibole formula $\mathrm{A} \mathrm{B}_{2}{ }^{\mathrm{vi}} \mathrm{C}_{5}{ }^{\mathrm{iv}} \mathrm{T}_{8} \mathrm{O}_{22}(\mathrm{OH})_{2}$, the cations' portioning was estimated as follows:

1. Sum $\mathrm{T}$ to 8.00 using $\mathrm{Si}$, then $\mathrm{Al}$, then $\mathrm{Ti}$.

2 Sum $\mathrm{C}$ to 5.00 using any excess $\mathrm{Al}$ and $\mathrm{Ti}$ from (1) and then successively $\mathrm{Fe}^{3+}, \mathrm{V}, \mathrm{Cr}, \mathrm{Mn}^{3+}$, $\mathrm{Zr}, \mathrm{Mg}, \mathrm{Zn}, \mathrm{Ni}, \mathrm{Co}, \mathrm{Fe}^{2+}, \mathrm{Mn}^{2+}$, Li.

3 Sum B to 2.00 using first any excess above 5.00 from C, in the reverse order of (2) starting with $\mathrm{Li}$ and then $\mathrm{Mn}^{2+}$ etc, and then follow with $\mathrm{Ca}, \mathrm{Sr}, \mathrm{Ba}$ and $\mathrm{Na}$.

4 Excess above 2.00 in $\mathrm{B}$ is assigned to $\mathrm{A}$ in the reverse order of (3), starting with $\mathrm{Na}$ and then finally all the $\mathrm{K}$ is allocated to $\mathrm{A}$.

Following the current amphibole nomenclature the minerals analysed in this study can be assigned to the Mg-Fe-Mn-Li group of amphiboles. The lack of Li data would not allow though assigning a specific root name to those amphiboles. The presence of abundant amphibole in the early volcanic products of the Akrotiri peninsula distinguishes them from the younger volcanics of Santorini, which generally lack amphibole.

\section{Discussion}

The presence of $\mathrm{Fe}-\mathrm{Mg}$ amphiboles in igneous rocks is rare and the only member known to occur in such rocks is cummingtonite. Rare it is, the presence of cummingtonite phenocrysts in silicic rocks, is considered as very important as an indicator of $\mathrm{P}_{\mathrm{H} 2 \mathrm{O}} / \mathrm{P}_{\text {total }}$ (Wood and Carmichael 1973) and a critical indicator of $\mathrm{T}, \mathrm{a}_{\mathrm{H} 20}$, and $\mathrm{f}_{02}$ in silicic volcanic rocks from shallow magma chambers (Evans and Ghiorso 1995). Carmichael et al. (1974) also noted that a $\mathrm{f}_{\mathrm{O} 2}$ control seems to exist for mafic phenocrysts in rhyolitic lavas.

The type of amphibole, analysed in this study, has not been reported before from volcanic rocks from the Aegean Sea Volcanic Arc and certainly they could not be considered as a common feature in such magmatic rocks.

Druitt et al. (1999) have found fibrous cummingtonite or anthophyllite, as alteration products though, replacing hypersthenes and greenish actinolite rimming or wholly replacing augites of mafic nodules of the Thera Pyroclastics. According to Gartzos et al. (1999) amphiboles, occurring as pheno- and xenocrysts in the rhyodacitic and dacitic rocks of Akrotiri, show a large variation in mineral chemistry, from $\mathrm{Mg}$-rich hastingsite through evolved hastingsite to hornblende. Mitropoulos and Tarney (1992) have reported problems in their attempts to analyse amphiboles from Santorini, posed by my large amounts of exsolved opaque oxides, leading to poor analytical results. Amphiboles from Methana, Aegina, Poros, Milos and Kos, the two ends of the Aegean Volcanic Arc, were classified, by the same authors, as Mg-hastingsite to Mg-hastingsite hornblende, whose $(\mathrm{Na}+\mathrm{K})^{\mathrm{A}}<0.50$ and tschermakite to $\mathrm{Mg}$-hornblende, whose $(\mathrm{Na}+\mathrm{K})^{\mathrm{A}}>0.50$. Davis et al. (1998) have reported the presence of amphibole in cognate mafic inclusions in silicic lavas and tuffs from the early centres of Akrotiri. Mortazavi and Sparks (2004) have analysed amphiboles in rhyolites and rhyodacites lavas and associated mafic inclusions from of the Akrotiri area. The amphiboles in the mafic inclusions were classified as typical calcic amphibole, plotting in the magnesiohastingsite and pargasite fields of the IMA 1997 nomenclature. The amphiboles in the silisic lavas, rhyodacites to low-Si rhyolites, were also classified as calcic amphibole, being divided into two compositional groups: a group of edenite with relatively low ${ }^{\text {iv }} \mathrm{Aliv}$ and ${ }^{\mathrm{A}}(\mathrm{Na}+\mathrm{K})$ and a group of intermediate composition between parolgasite and magnesiohastingsite with high ${ }^{\text {iv }} \mathrm{Al}$ and ${ }^{\mathrm{A}}(\mathrm{Na}+\mathrm{K})$. The second group is similar to the amphiboles of the mafic inclusions and they were interpreted as xenocrysts by the same authors. However, some amphiboles were reported to have intermediate compositions between these two groups.

The knowledge of the chemical composition of a single mineral phase would not lead to sound conclusions regarding magma evolution and petrogenetic procedures. The mineral chemistry of the 
other pyrogenic phases present need to be examined. Further investigation is also needed to examine these $\mathrm{Mg}-\mathrm{Fe}$ rich phases in relation to the involvement of pyroxenic units in their structure (pyriboles molecules). The presence, however, of such a unique high $\mathrm{Mg}$-Fe mineral phase in silicic pyroclastic rocks in Santorini is certainly constant with the involvement of more primitive, mantle derived, mafic magmas, with some considerable $\mathrm{H}_{2} \mathrm{O}$ content, and which have been probably differentiated, before they are mixed with more silicic magmas at a shallower crustal level.

\section{References}

Burke, E.A.J., and Leake, B.E., 2005. "Named Amphiboles": A new category of amphiboles recognized by the International Mineralogical Association (IMA) and a defined sequence order for the use of prefixes in amphibole names, American Mineralogist, 90, 516-517.

Carmichael, I.S.E., Turner, C.J., and Verhoogen, J., 1974. Igneous Petrology, McGraw-Hill, New York, 730pp.

Davis, E., Gartzos, E., and Dietrich, V.J., 1998. Magmatic Evolution of the Pleistocene Akrotiri Volcanoes. In R. Casale, et al. (eds), Proceedings of the $2^{\text {nd }}$ workshop, "The European Laboratory Volcanoes", Santorini, 2-4 May 2-4 1996, 49-68.

Dietrich, V.J., Davis, E., and Gartzos, E., 1998. Amphibole in rhyodacites and dacites from the Akrotiri volcanoes and the complexities of discontinuous fractional crystallization. In R. Casale, et al (eds), Proceedings of the $2^{\text {nd }}$ workshop, "The European Laboratory Volcanoes", Santorini, 2-4 May 2-4 1996, 69-80.

Druitt, T.H., Edwards, L., Mellors, R.M., Pyle, D.M., Sparks, R.S.J., Lanphere, M., Davies, M., and Barriero, B., 1999. Santorini Volcano, Geological Society, London, Memoirs, 19, $165 \mathrm{pp}$.

Evans, B.W., and Ghiorso, M.S., 1995. Thermodynamics and petrology of cummingtonite, American Mineralogist, 80, 649-663.

Fouque, F., 1879. Santorin et ses Eruptions, Paris, G. Masson, 440pp.

Gartzos, E., Dietrich, V.J., and Davis, E., 1999. Amphibole-plagioclase fractional crystallisation and magma mixing as major differentiation processes in the Akrotiri Volcanic Complex, Santorini, Greece, Schweiz. Mineral. Petrogr. Mitt., 79 (2), 231-262.

Huijsmans, J.P.P., Barton, M., and Salters, V.J.M., 1988. Geochemistry and evolution of calcalkaline volcanic complex of Santorini, Aegean Sea, Greece, J. Volcanology Geothermal. Research, 34, 283-306.

Kitsopoulos, K.P., 1995. The mineralogy, geochemistry, physical properties and possible industrial applications of volcanic zeolitic tuffs from Santorini and Polyegos islands, Greece, PhD Thesis, University of Leicester, 442pp.

Kitsopoulos, K.P., 1996. Zeolitization of the Akrotiri pre-caldera pyroclastics from Santorini island, Greece. Implications for existing zeolitization models as applied with volcaniclastic materials, GSA Abstracts with Programs 1996, 28 (7), A-104.

Kitsopoulos, K.P., Scott, P.W., Jeffrey, C.A., and Marsh, N.G., 2001. The mineralogy and geochemistry of zeolite-bearing volcanics from Akrotiri (Santorini Island) and Polyegos (Milos group of Islands), Greece. Implications for geochemical classification diagrams, Bull. Geol. Soc. Greece, XXXIV/3, 859-865.

Leake, B.E., 1978. Nomenclature of Amphiboles, Mineralogical Magazine, 42, 533-569.

Leake, B.E., Woolley, A.R., Arps, C.E.S., Birch, W.D., Gilbert, M.C., Grice, J.D., Hawthorne, 
F.C., Kato, A., Kisch, H.J., Krivovichev, V.G., Linthout, K., Laird, J., Mandarino, J.A., Maresch, W.V., Nickel, E.H., Rock, N.M.S., Schumacher, J.C., Smith, D.C., Stephenson, N.C.N., Ungaretti, L., Whittaker, E.J.W., and Youzhi, G., 1997. Nomenclature of amphiboles: Report of the Subcommittee on Amphiboles of the International Mineralogical Association, Commission on New Minerals and Mineral Names, American Mineralogist, 82, 1019-1037.

Leake, B.E., Woolley, A.R., Birch, W.D., Burke, E.A.J., Ferraris, G., Grice, J.D., Hawthorne, F.C., Kisch, H.J., Krivovichev, V.G., Schumacher, J.C., Stephenson, N.C.N., and Whittaker, E.J.W., 2004. Nomenclature of amphiboles: additions and revisions to the International Mineralogical Association's amphibole nomenclature, American Mineralogist, 89, 883-887.

Mitropoulos, P. and Tarney, J., 1992. Significance of mineral composition variations in the Aegean Island Arc, Journal Volcanology Geothermal Research, 51, 283-303.

Mogessie, A., Ettinger, K., Leake, B.E., and Tessadri, R., 2001. AMPH-IMA97: a hypercard program to determine the name of an amphibole from electron microprobe and wet analyses, Computers and Geosciences, 27, 1169-1178.

Mortazavi, M., and Sparks, R.S.J., 2004. Origin of rhyolite and rhyodacite lavas and associated mafic inclusions of Cape Akrotiri, Santorini: the role of wet basalt in generating calcalkaline silicic magmas, Contributions Mineralogy and Petrology, 146, 397-413.

Nickel, E.H., and Grice, J.D., 1998. The IMA Commission on New Minerals and Mineral Names: procedures and guidelines on mineral nomenclature, Canadian Mineralogist, 36, 913-926.

Nicholls, I.A., 1971. Petrology of Santorini volcanic rocks, J Petrol., 12, 67-119.

Oberti, R., Cámara, F., Ottolini, L., and Caballero, J.M., 2003. Lithium in amphiboles: detection, quantification and incorporation mechanisms in the compositional space bridging sodic and ${ }^{\mathrm{B}} \mathrm{Li}$ amphibole, European Journal of Mineralogy, 15, 309-319.

Pichler, H., and Kussmaul, S., 1972. The calc-alcaline volcanics rocks of the Santorini Group (Aegean Sea, Greece), N. J. Miner. Abh., 116, 268-307N.

Tsolis-Katagas, P., and Katagas, C., 1989. Zeolites in Pre-Caldera pyroclastic rocks of the Santorini Volcano, Aegean Sea, Greece, Clays and Clay Minerals, 37, 497-510.

Winchester, J.A., and Floyd, P.A., 1977. Geochemical discrimination of different magma series and their differentiation products using immobile elements, Chemical Geology, 20, 325343.

Wood, B.J., and Carmichael, I.S.E, 1973. $\mathrm{P}_{\text {total }}, \mathrm{P}_{\mathrm{H} 2 \mathrm{O}}$, and the occurrence of cummingtonite in volcanic rocks, Contributions Mineralogy Petrology, 40, 149-158. 